\title{
Differential responses of oat cultivars to phosphate deprivation: plant growth and acid phosphatase activities
}

\author{
Ewa Żebrowska $\cdot$ Elżbieta Bujnowska • \\ Iwona Ciereszko
}

Received: 17 June 2011/Revised: 23 November 2011/Accepted: 7 December 2011/Published online: 24 December 2011

(C) The Author(s) 2011. This article is published with open access at Springerlink.com

\begin{abstract}
The effect of phosphate starvation on growth and acid phosphatases (APases) localization and activity in oat tissues was investigated. Oat cultivars (Avena sativa L.Arab, Polar, Szakal) were grown for 1-3 weeks in complete nutrient medium $(+\mathrm{P})$ and without phosphate $(-\mathrm{P})$. Pi concentration in plant tissues decreased strongly after culturing on -P medium. Pi deficit reduced shoot growth, stimulated root elongation and increased ratio of root/shoot in all oat cultivars. Pi deficit had a greater impact on growth of oat cv. Polar than other varieties. A decrease in the internal Pi status led to an increase of acid phosphatase activities in extracts from shoots and roots, and in root exudates. The highest activity of secreted APases was observed for oat cv. Arab, during the third week of growth under Pi-deficient conditions. The activity of extracellular APase was high in young, growing zones of roots of -P plants. Histochemical visualization indicated high activity of APases in the epidermis and vascular tissues of -P plants. Pi deficiency increased intracellular APase activity in shoot mainly in oat cv. Polar, whereas APase activity in roots was the highest in oat cv. Szakal. Protein extracts from roots and shoots were run on native discontinuous PAGE to determine which isoform(s) may be affected by Pi deficiency. Three major APase isoforms were detected in all oat plants; one was strongly induced by Pi deficit. The studied oat cultivars differed in terms of acclimation to deficiency of phosphate-used various pools of APases to acquire Pi from external or internal sources.
\end{abstract}

Communicated by L. A. Kleczkowski.

E. Żebrowska · E. Bujnowska · I. Ciereszko $(\bowtie)$

Department of Plant Physiology, Institute of Biology,

University of Bialystok, Swierkowa 20b,

15-950 Bialystok, Poland

e-mail: icier@uwb.edu.pl
Keywords Avena sativa - Extracellular acid phosphatase - Enzyme localization - Pi deficit . Root exudates

$\begin{array}{ll}\text { Abbreviations } \\ \text { APase } & \text { Acid phosphatase } \\ \text { PAGE } & \text { Polyacrylamide gel electrophoresis } \\ \mathrm{Pi} & \text { Inorganic phosphate } \\ -\mathrm{P} & \text { Plants cultured on medium without phosphate } \\ +\mathrm{P} & \text { Control plants }\end{array}$

\section{Introduction}

Phosphorus plays an important role in various processes such as organic compounds biosynthesis, photosynthesis, respiration and energy transfer, regulation of enzymes activity, and gene expression or signal transduction (Maleszewski et al. 2004; Ciereszko et al. 2005; Ciereszko and Kleczkowski 2005; Rychter and Rao 2005; Yang and Finnegan 2010; Yao et al. 2011). Availability of phosphorus determines the plant growth, development, reproduction, and crop yield (Marschner 1995). Plants absorb only inorganic phosphate $(\mathrm{Pi})$ but most soil phosphorus exists as insoluble complexes, e.g., aluminum and ferrous phosphates or inaccessible to plants organic forms (Marschner 1995; Vance et al. 2003). Phosphorus is frequently the most limiting element for cultivated plants. Application of phosphorus-rich fertilizers is recommended in agriculture for enhancing Pi availability and stimulating crop yield. However, the inexpensive rock phosphate reserves may be soon depleted (Vance et al. 2003; Cordell et al. 2009). As the inorganic phosphorus sources are non-renewable, further investigations and selection of cultivars tolerant to Pi 
depletion are very important in order to sustain or improve crop productivity (Shenoy and Kalagudi 2005; Cordell et al. 2009).

Plants have developed many strategies to liberate phosphorus, including organic acid exudation from roots or secretion of enzymes, e.g., acid phosphatases (Schachtman et al. 1998; Guame et al. 2001; Vance et al. 2003; Nilsson et al. 2010). Pi absorption might be facilitated by expression of Pi transporters or via modifications of root system, strictly controlled and regulated at the molecular level (Żebrowska and Ciereszko 2007; Desnos 2008; Fang et al. 2009; Yang and Finnegan 2010). Modifications of root morphology, like increase of root length or lateral root and root hair density, enhance the total surface area available for soil exploration and nutrient acquisition (Schachtman et al. 1998; Svistoonoff et al. 2007; Desnos 2008). In response to $\mathrm{Pi}$ deficiency plants can develop proteoid roots or activate colonization of roots by mycorrhizal fungi (Vance et al. 2003; Shane and Lambers 2005).

Acid phosphatases (orthophosphoric monoester phosphohydrolase, APases, EC 3.1.3.2) hydrolyze different forms of organic phosphorus at low $\mathrm{pH}$, usually non-specifically. APases are ubiquitous and abundant in different tissues of plants or animals, in fungi and bacteria, and they are involved in the production, transport, and recycling of $\mathrm{Pi}$, which are crucial for cellular metabolism and bioenergetics (Duff et al. 1994; Olczak et al. 2003). Various developmental and environmental conditions may influence gene expression, protein synthesis, and activity of APases in plant tissue or in soil (Duff et al. 1994; Żebrowska and Ciereszko 2009). Activities of both extracellular and internal APases might increase in response to phosphorus depletion and several plants can secrete APase from roots to the rhizosphere (Duff et al. 1994; Gilbert et al. 1999; Wasaki et al. 2008; Tran et al. 2010). Extracellular APases are involved in Pi release from organic phosphate monoesters in soils, whereas intracellular APases are thought to be pivotal in the remobilization of $\mathrm{Pi}$ from phosphorus-rich components in cells (Duff et al. 1994; Tomscha et al. 2004; Tran et al. 2010). The secreted or cell wall-bound APases are important for phosphate nutrition and homeostasis (Tomscha et al. 2004). Transgenic plants with high expression of acid phosphatase genes (e.g., MtPAPl or $L A S A P 2$ ) generally have improved $\mathrm{Pi}$ acquisition and better biomass production (Xiao et al. 2006; Wasaki et al. 2009; Tran et al. 2010). The overexpression of APase genes might be an effective approach to improve Pi acquisition by crop plants in the future, when organic $\mathrm{P}$ will be the main source of phosphorus in agriculture (Cordell et al. 2009).

Enhanced activities and synthesis of APases under phosphate-deficient condition have been documented in tissues of various plants, including barley, clover, cucumber, lupine, maize, rice, soybean, tomato, and wheat (Asmar et al. 1995; Ciereszko et al. 2002, 2011a, b; Ming et al. 2002; George et al. 2008). The APase activity may differ between plant species and genotypes, e.g. in barley, clover or maize (Hunter and McManus 1999; Ciereszko et al. 2011b). Generally, the duration of Pi deficiency (and level of Pi concentration in soil or tissue) has significant impact on APase activities associated with plant roots (or present in the rhizosphere) (Duff et al. 1994; Żebrowska and Ciereszko 2009; Tran et al. 2010). However, some studies show negative relationship between APase activity and Pi uptake efficiency under phosphate starvation (Yan et al. 2001; Yun and Kaeppler 2001). In addition, other results indicated that APase activity of roots is a poor indicator of growth and Pi nutrition under a range of soil conditions (George et al. 2008). Therefore, the role of APases in plant acclimation to low-Pi stress is still not clear.

In this study, we investigated the morphological and physiological responses of three oat cultivars to $\mathrm{Pi}$ deficiency stress during early plant growth, critical to tillering and further productivity. Oat (Avena sativa L.) is an important grain crop, usually grown in poor soils, but there are not many studies focused on its acclimatization mechanisms to low-Pi conditions. The main goals of our study were to investigate differences in secretion, localization, and activities of APases among oat varieties, and estimate the role of APases under Pi starvation.

\section{Materials and methods}

Plant material and culture

Three oat (Avena sativa L.) commercial cultivars: Arab (registered in 2004), Polar (2002) and Szakal (2000) recommended for farmers, were selected in the preliminary experiments among other several oat genotypes. Seedlings, after 7 days of germination (in growth chamber), were grown hydroponically in complete nutrient medium $(+\mathrm{P}$, control) or without phosphate $(-\mathrm{P})$ as described by Ciereszko et al. (1996), with some modifications. Complete nutrient medium consisted of: $\mathrm{Ca}\left(\mathrm{NO}_{3}\right)_{2} \cdot 4 \mathrm{H}_{2} \mathrm{O}(4.4 \mathrm{mM})$,

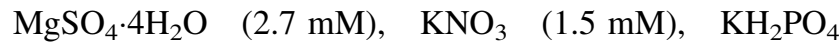
(1.1 mM), Fe-EDTA $(76 \mu \mathrm{M}), \quad \mathrm{H}_{3} \mathrm{BO}_{3} \quad(43 \mu \mathrm{M})$, $\mathrm{MnCl}_{2} \cdot 4 \mathrm{H}_{2} \mathrm{O}(9 \mu \mathrm{M}), \mathrm{CuSO}_{4} \cdot 5 \mathrm{H}_{2} \mathrm{O}(0.3 \mu \mathrm{M}), \mathrm{ZnSO}_{4}$. $7 \mathrm{H}_{2} \mathrm{O}(0.8 \mu \mathrm{M}), \mathrm{H}_{2} \mathrm{MoO}_{4} \cdot 4 \mathrm{H}_{2} \mathrm{O}(0.1 \mu \mathrm{M})$. In $-\mathrm{P}$ medium instead of $\mathrm{KH}_{2} \mathrm{PO}_{4}, \mathrm{KCl}(2 \mathrm{mM})$ was added. The plants were cultured in plastic containers ( 15 seedlings per 51 of nutrition medium); culture media were adjusted to $\mathrm{pH}$ 5.7, continuously aerated and replaced every 4-5 days. The plants were cultured in a growth chamber with a light period of $16 \mathrm{~h}(8 \mathrm{~h}$ dark $), P A R-150 \mu \mathrm{mol} \mathrm{m}{ }^{-2} \mathrm{~s}^{-1}$, 
temperature $-23 / 19^{\circ} \mathrm{C}$ (day/night) and about $60 \%$ relative humidity. Plant material was collected about 3-4 h after the beginning of light period. Oat plants were harvested after 1, 2, and 3 weeks of growth on nutrient media (14-, 21-, and 28-day-old plants, respectively).

Inorganic phosphate determination

An aliquot of $0.5 \mathrm{~g}$ of roots or leaves was frozen in liquid nitrogen and thereafter tissue was homogenized in $10 \%(\mathrm{v} / \mathrm{v})$ trichloroacetic acid (TCA) at $4^{\circ} \mathrm{C}$ (Ciereszko et al. 2002). The homogenate was diluted with $5 \%$ TCA and incubated for about $30 \mathrm{~min}$. Inorganic phosphate (Pi) concentration was determined in the filtrate using phosphomolybdate colourimetric assay with Ames reagent (absorbances were read at 700 nm, Cecil CE 2501).

Secreted acid phosphatase activity measurements

For root surface and secreted acid phosphatase assay, intact root system (or fragments of oat roots-about $1.5 \mathrm{~cm}$ long root tips and mature part of roots) were washed in distilled water, blot dried, placed into 30-50 $\mathrm{ml}$ (depending on root size) of incubation medium with substrate mixture $(6 \mathrm{mM}$ $p$-nitrophenyl phosphate- $p$ NPP and $1 \mathrm{mM}$ dithiothreitol in $50 \mathrm{mM}$ sodium acetate buffer, $\mathrm{pH} 5.0$ ), and incubated at $25^{\circ} \mathrm{C}$. To $200 \mu \mathrm{l}$ aliquots of the reaction medium (collected at different intervals for $2 \mathrm{~h}$ ) were added $200 \mu \mathrm{l}$ of $4 \mathrm{M}$ $\mathrm{NaOH}$ (to stop reaction) and the absorbances were read at $410 \mathrm{~nm}$ (Cecil CE 2501). The results after $15 \mathrm{~min}$ of root incubation are presented; enzyme activity was expressed as micromoles of $p \mathrm{NP}$ per minute per grams of $\mathrm{FW}$ (Ciereszko et al. 2002).

In vivo APase activity staining

Secretion of APases was determined by in vivo activity stain as described before by Ciereszko et al. (2011a, b). Therefore, an intact roots (after 1 week of growth on nutrient media) were rinsed in sodium acetate buffer (0.1 mM, pH 5.0) and embedded in $2 \%$ agarose and substrate mixture $(0.2 \%$ 1-naphthyl phosphate, $0.2 \%$ Fast Blue $\mathrm{B}$ in $100 \mathrm{mM}$ sodium acetate buffer, $\mathrm{pH}$ 5.0). The Petri dishes were placed in the refrigerator for 2-24 h (after agarose set at room temperature). A dark purple colour indicated acid phosphatase activity in roots and root exudates as compared to heat-killed tissue (control).

Distribution of APase activity in root cross-sections

Root cross-sections (maturation zone of roots) were rinsed in sodium acetate buffer $(0.1 \mathrm{mM}, \mathrm{pH} 5.0)$ and incubated in substrate mixture (0.2\% 1-naphtyl phosphate, $0.2 \%$ Fast Blue $\mathrm{B}$ in $100 \mathrm{mM}$ sodium acetate buffer, $\mathrm{pH}$ 5.0). After 20-min incubation, root fragments were washed in distilled water and photographed under light microscope (Olympus BX41). A dark brown/purple colour indicated acid phosphatase activity in the root tissues (Ciereszko et al. 2011b).

Intracellular APase activity assays

Intracellular acid phosphatase activity was determined in extracts from shoots and roots of all oat cultivars. For protein extraction, tissue samples $(0.5 \mathrm{~g})$ were ground in liquid nitrogen, the extraction buffer $(50 \mathrm{mM}$ sodium acetate buffer, pH 5.0 with $1 \mathrm{mM}$ DTT) was added, then extracts were centrifuged at $12,000 \mathrm{~g}$ for $10 \mathrm{~min}$ at $4^{\circ} \mathrm{C}$ (Ciereszko et al. 2002, 2011a, b). Enzyme activity was determined after 5-60 min of incubation with $6 \mathrm{mM}$ p-nitrophenyl phosphate (in $100 \mathrm{mM}$ sodium acetate buffer, $\mathrm{pH} 5.0$ ) at $37^{\circ} \mathrm{C}$; the reaction was terminated with $\mathrm{NaOH}$. The results after $15 \mathrm{~min}$ incubation are presented and expressed as micromoles of $p \mathrm{NP}$ per minute per milligram of protein.

\section{Protein estimations}

Protein concentration in different tissue extracts was determined spectrophotometrically at $595 \mathrm{~nm}$ (Cecil CE 2501) according to Bradford method (1976), with the bovine serum albumin as the standard.

Analysis of intracellular acid phosphatase isoforms

Root and shoot tissues were ground in a liquid nitrogenchilled mortar, $4 \mathrm{ml}$ extraction buffer (100 mM sodium acetate, pH 5.0; 2 mM EDTA; 5 mM DTT; $20 \mathrm{mM} \mathrm{CaCl}_{2}$, and $60 \mathrm{mg}$ PVPP) was added per $1 \mathrm{~g}$ tissue. The solution was gently mixed at $4{ }^{\circ} \mathrm{C}$ for $60 \mathrm{~min}$, then centrifuged at $10,000 \mathrm{~g}$ and the pellet discarded. $1 \mu \mathrm{g}$ proteins from root extracts and $10 \mu \mathrm{g}$ proteins from shoots, per lane, were loaded into discontinuous native polyacrylamide gel $(5 \%$ $\mathrm{w} / \mathrm{v}$ stacking gel and $10 \% \mathrm{w} / \mathrm{v}$ resolving gel); protein concentration in root extracts was much lower than in shoots. Electrophoresis was carried out using a mini-gel system (Hoefer SE 260, Amersham). The native gels were run at $4^{\circ} \mathrm{C}$ and washed three times in $0.1 \mathrm{mM}$ sodium acetate buffer $(\mathrm{pH}$ 5.0). Approximate masses of APase isoforms were estimated with protein molecular marker (Full Range Rainbow Molecular Weight Markers, Amersham). Native gels were poured with $300 \mu \mathrm{g} / \mathrm{ml}$ of 4-methylumbelliferyl phosphate in $100 \mathrm{mM}$ sodium acetate, $\mathrm{pH} 5.0$ and $1 \%$ agarose (w/v). The fluorescence of methylumbelliferone liberated by phosphatase activity was visualized and documented under UV light (Gel Doc 2000, Quantity One version 4.1, Bio-Rad) 
after $10 \mathrm{~min}$ incubation, as described by Ciereszko et al. (2011b).

\section{Statistical analysis}

All experiments were performed in three to five independent series, in at least three replicates of determinations, and standard deviation (SD) was calculated. Means were compared between the treatments at the 0.05 probability level (using Student- $t$ test).

\section{Results}

Pi concentration and growth of oat cultivars

The growth of oat plants (Avena sativa L., cv.: Arab, Polar, Szakal) for 3 weeks in phosphate-deficient $(-\mathrm{P})$ nutrient medium resulted in low inorganic phosphate content in tissues, changes of growth parameters and higher activity of acid phosphatases.

The growth in $-\mathrm{P}$ medium significantly decreased $\mathrm{Pi}$ concentration in leaves and roots of plants, already after 1-2 weeks (data not shown). After 3 weeks of culture in $-\mathrm{P}$ medium, $\mathrm{Pi}$ concentration in $-\mathrm{P}$ shoot of oat $\mathrm{cv}$. Arab was about $6 \%$ of that found in $+\mathrm{P}$ plant, in the Polar shoot-4\% and in Szakal-9\%; Pi in roots was about 5, 3, and $8 \%$, respectively, of the control (Table 1).

The fresh masses of shoots and roots were similar in plants cultured for 1 week in $+\mathrm{P}$ and $-\mathrm{P}$ nutrient media, but after 2 weeks under Pi deficiency, the shoot weight decreased (data not shown). After 3 weeks of culture in $-\mathrm{P}$ medium, shoot fresh mass of oat cv. Arab, Polar and Szakal was 25, 14 and 27\%, respectively, of control. The root fresh mass of oat cv. Arab, Polar and Szakal was 1.7-,
2.8- and 1.6-folds higher, respectively, than control plants (Table 1). The ratio of root/shoot weight was higher in $-\mathrm{P}$ oat plants than $+\mathrm{P}$ plants, the highest ratio was observed in oat cv. Polar. The changes in dry masses of oat shoots and roots were similar to changes of fresh weight (Table 1). The decrease of shoot mass of Pi-deficient oat was accompanied by a decrease in shoot height. After 3 weeks on $-\mathrm{P}$ medium, the shoot height of Arab, Polar and Szakal was 66,49 , and $71 \%$ of the control. The root length of oat cv. Arab, Polar and Szakal was about 1.3-, 1.2- and 1.6-folds higher, respectively, than control. The ratio of root length to shoot height was higher in $-\mathrm{P}$ plants than $+\mathrm{P}$ plants (Table 1).

The water content in the tissues of all oat cultivars was about $90 \%$ in shoots and roots and was not significantly affected by Pi deficiency, especially at the beginning of culture (data not shown). However, after 3-week-culture, Pi deficit slightly modified water relations in the root of the oat cv. Polar.

Acid phosphatases secretion by oat roots and APase activity under Pi deficiency

Extracellular APase activity, secreted from roots to the incubation medium, was significantly altered by Pi deficiency (Fig. 1). After 1 week of culture, the APase activity secreted by intact roots of the $-\mathrm{P}$ oat $\mathrm{cv}$. Arab increased by $67 \%$, Polar-23\% and Szakal-73\%, as compared with $+\mathrm{P}$ plants (Fig. 1). After 2 weeks, APase activity increased about 2.8-, 1.8-, and 1.5-folds, respectively for -P Arab, Polar, and Szakal; after 3 weeks of Pi deficiency, enzymes activity was about 5-, 2.5-, and 1.6-fold higher than in control (Fig. 1). The APase activity associated with root tips from Pi-deficient oat plants was always higher (above two-folds) than that from the control (data not shown).

Table 1 Pi content and growth parameters of oat (Avena sativa L. cv. Arab, Polar, Szakal) plants cultured for 3 weeks in phosphate-sufficient $(+\mathrm{P})$ or phosphate-deficient $(-\mathrm{P})$ nutrient medium

\begin{tabular}{|c|c|c|c|c|c|c|}
\hline \multirow[t]{2}{*}{ Parameters } & \multicolumn{2}{|l|}{ Arab } & \multicolumn{2}{|l|}{ Polar } & \multicolumn{2}{|l|}{ Szakal } \\
\hline & $+\mathrm{P}$ & $-\mathrm{P}$ & $+\mathrm{P}$ & $-\mathrm{P}$ & $+\mathrm{P}$ & $-\mathrm{P}$ \\
\hline $\mathrm{Pi}$ in shoot $\left(\mu \mathrm{g} \mathrm{g}^{-1} \mathrm{FW}\right)$ & $616 \pm 35$ & $35 \pm 5$ & $647 \pm 17$ & $29 \pm 5$ & $585 \pm 67$ & $52 \pm 22$ \\
\hline $\mathrm{Pi}$ in roots $\left(\mu \mathrm{g} \mathrm{g}^{-1} \mathrm{FW}\right)$ & $400 \pm 38$ & $21 \pm 4$ & $516 \pm 39$ & $14 \pm 5$ & $479 \pm 67$ & $39 \pm 7$ \\
\hline Shoot fresh weight (g) & $2.8 \pm 0.16$ & $0.71+0.1$ & $2.2 \pm 0.19$ & $0.32 \pm 0.04$ & $2.4 \pm 0.15$ & $0.64 \pm 0.08$ \\
\hline Roots fresh weigth $(\mathrm{g})$ & $0.88 \pm 0.18$ & $1.5+0.13$ & $0.46 \pm 0.04$ & $1.31+0.21$ & $0.81 \pm 0.07$ & $1.31 \pm 0.05$ \\
\hline Root/shoot & 0.31 & 2.11 & 0.21 & 4.1 & 0.34 & 2.05 \\
\hline Shoot dry weight (mg) & $280 \pm 21$ & $67 \pm 14$ & $276 \pm 44$ & $28 \pm 6$ & $241 \pm 19$ & $65 \pm 13$ \\
\hline Roots dry weigth (mg) & $92 \pm 16$ & $141 \pm 17$ & $81 \pm 18$ & $132 \pm 22$ & $78 \pm 12$ & $121 \pm 10$ \\
\hline Shoot height $(\mathrm{cm})$ & $48.4 \pm 2.2$ & $32 \pm 2.3$ & $43.8 \pm 2.1$ & $21.4 \pm 1.8$ & $51.5 \pm 1.6$ & $36.6 \pm 3.4$ \\
\hline Root length (cm) & $43.1 \pm 2.1$ & $55.6 \pm 5$ & $33.5 \pm 1.5$ & $41.7 \pm 5$ & $36.6 \pm 2.6$ & $57.6 \pm 3.1$ \\
\hline Root/shoot & 0.89 & 1.74 & 0.76 & 1.95 & 0.71 & 1.57 \\
\hline
\end{tabular}

Means \pm SD values are indicated. All differences are statistically important at 0.05 


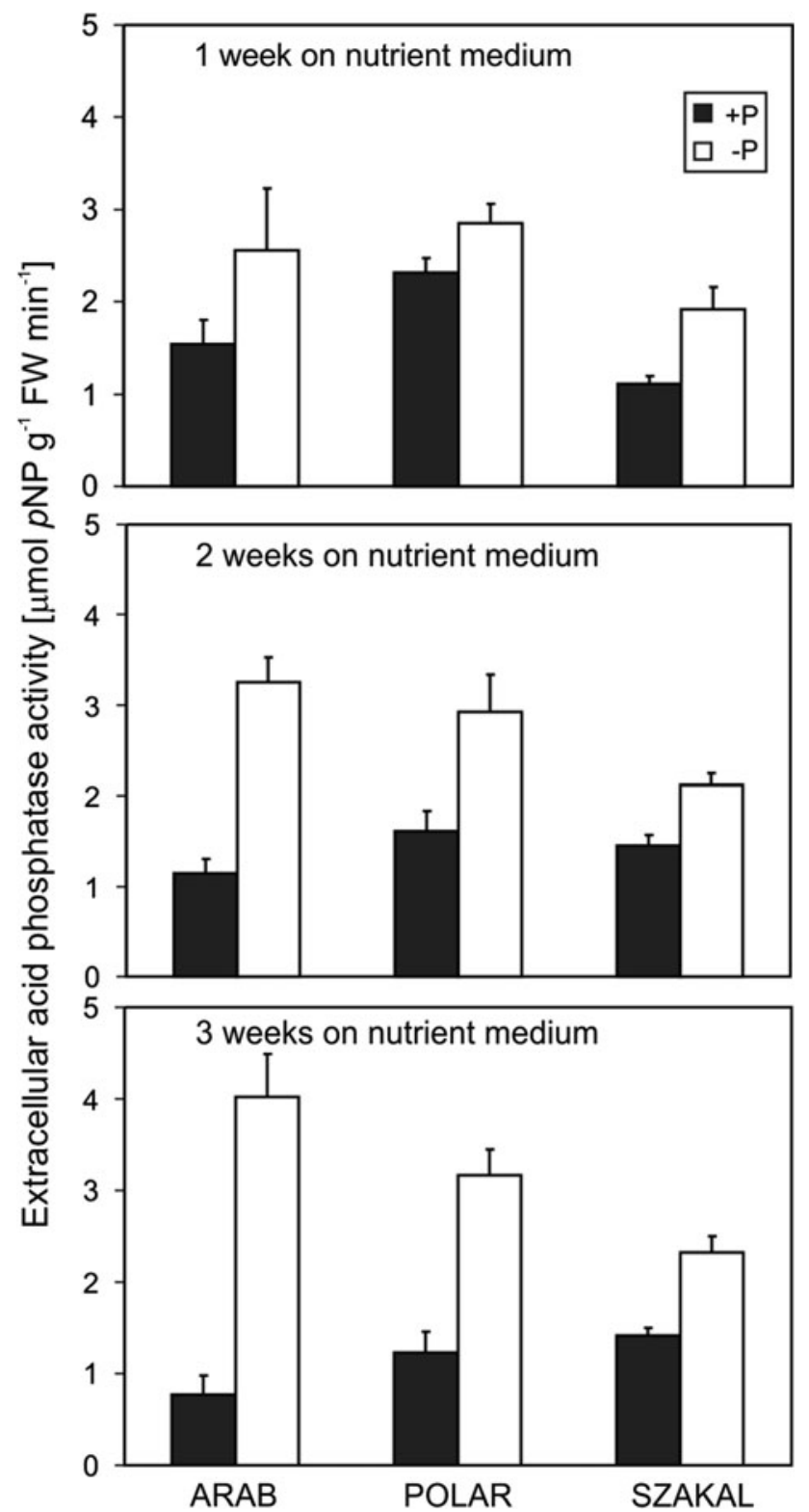

Fig. 1 Extracellular acid phosphatase activity ( $\mu \mathrm{mol} p \mathrm{NP} \mathrm{g}^{-1}$ $\mathrm{FW} \min ^{-1}$ ) secreted by intact roots of three oat (Avena sativa $\mathrm{L}$.) varieties (Arab, Polar, and Szakal) grown for 1, 2, and 3 weeks in phosphate-sufficient $(+\mathrm{P})$ or phosphate-deficient $(-\mathrm{P})$ nutrient medium (means $\pm \mathrm{SD}$ ). All differences between treatments are statistically important at 0.05

The APase activity in young, growing zones of roots of $-\mathrm{P}$ oat plants (after 2-week-culture) was about 4-5 $\mu \mathrm{mol} p \mathrm{NP} \mathrm{g}^{-1}$ $\mathrm{FW} \mathrm{min}{ }^{-1}$ (in $+\mathrm{P}$-about $1.5 \mu \mathrm{mol} p \mathrm{NP} \mathrm{g}^{-1} \mathrm{FW} \mathrm{min}^{-1}$ ), whereas in the mature root parts the activity was lower.

The in vivo activity stain for root surface acid phosphatase showed higher enzyme secretion by intact roots of all Pi-deficient oat varieties, as compared with $+\mathrm{P}$ plants (Fig. 2a). Histochemical APase activity staining was carried out on cross-sections of roots of oat plants hydroponically grown under Pi-sufficient and Pi-deficient conditions (Fig. 2b). The intensity of brown/purple colour, indicating APase activity, was generally stronger in $-\mathrm{P}$ roots than in $+\mathrm{P}$ roots (Fig. $2 b$ ). Transverse sections of $-\mathrm{P}$ roots of Szakal showed strong signal of APase activity (Fig. 2c). APase activities differed considerably between root tissues; high enzyme activity was found mainly in the epidermis and vascular tissue of $-\mathrm{P}$ plants (Fig. 2b, c).

Intracellular acid phosphatases activity was estimated in extracts from shoots and roots of studied oat cultivars (Fig. 3). An increase in shoot APase activity was observed in Pi-deficient oat cv. Polar: after 1 week of culture-about 1.7-fold, 2 weeks-two-fold, after 3 weeks about 3.7-fold increase, as compared to $+\mathrm{P}$ plants (Fig. 3a). APase activity in crude extracts from shoots of $-\mathrm{P}$ oat cv. Arab and Szakal was similar to that of the $+\mathrm{P}$ plants, or decreased by about 40-50\% (Fig. 3a). The enzyme activity in extracts from roots generally increased after 2-3 weeks of Pi deficiency, when compared with control (Fig. 3b). The APase activity in roots of $-\mathrm{P}$ oat $\mathrm{cv}$. Polar after 3 weeks of culture increased about 2.2-folds and in Szakal-about 6.5-folds, as compared to control (Fig. 3b). Soluble protein content in enzymatic extracts from shoots and roots of three oat varieties was not significantly affected by Pi deficiency; the protein content in the shoots of oat was significantly higher than in roots (data not shown).

To examine APase isoforms, the proteins isolated from shoots and roots of three oat cultivars were separated on native PAGE and stained for APase activity (with 4-methylumbelliferyl phosphate). In extracts from all tissues of oat varieties, at least three major APase isoforms with lower and higher mobility on the gel (approximately about 95, 70, and $27 \mathrm{kDa}$ ) were detected (Fig. 4). Especially, one of these isoforms (approximately $27 \mathrm{kDa}$ ) was strongly induced by Pi deficiency in shoot extracts. During 3 weeks of plant growth the isoformic pattern of APase was basically unchanged (data not shown), although in oat cultured for 3 weeks higher activity of one isoform (approximately $95 \mathrm{kDa}$ ) was observed in shoots and roots of $-\mathrm{P}$ plants, than in the oat varieties cultured for 1 week (Fig. 4).

\section{Discussion}

Effects of Pi deficiency on plants growth

The lack of phosphate in the nutrient medium affected growth of all studied oat cultivars: the shoot growth was significantly reduced but the root elongation was stimulated. When comparing oat varieties, the largest decrease of shoot weight and the largest root mass increase occurred in 
A

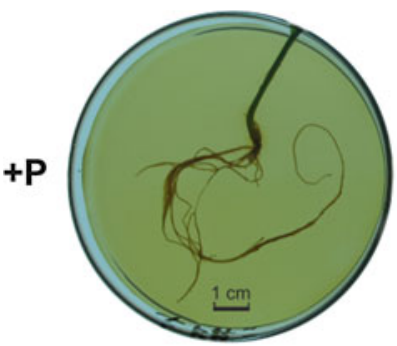

CONTROL
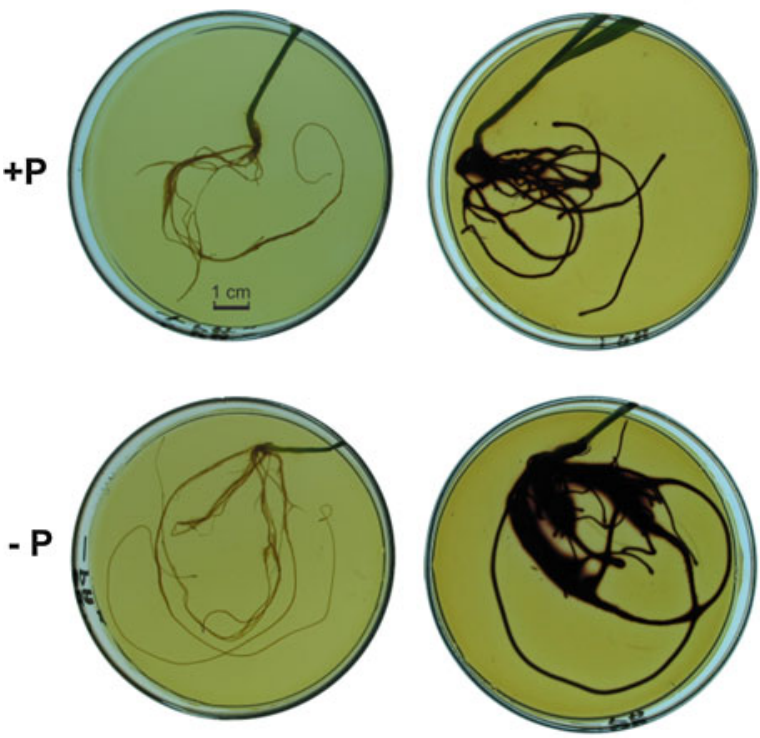

B
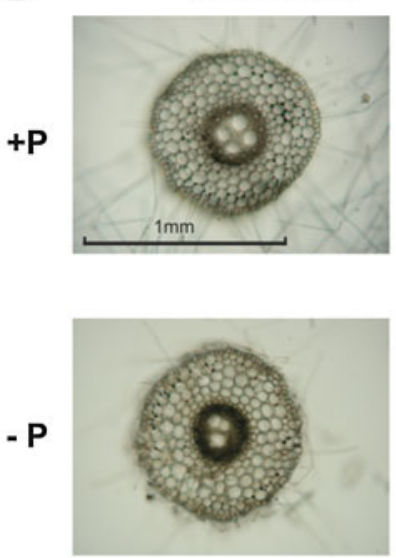

ARAB

ARAB
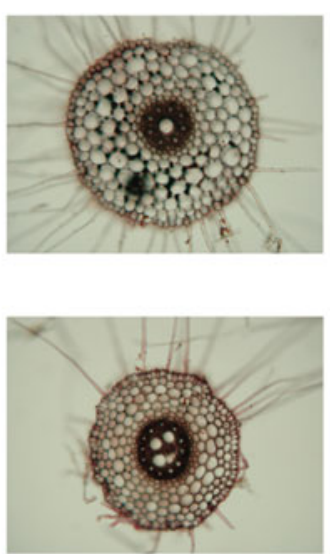

POLAR
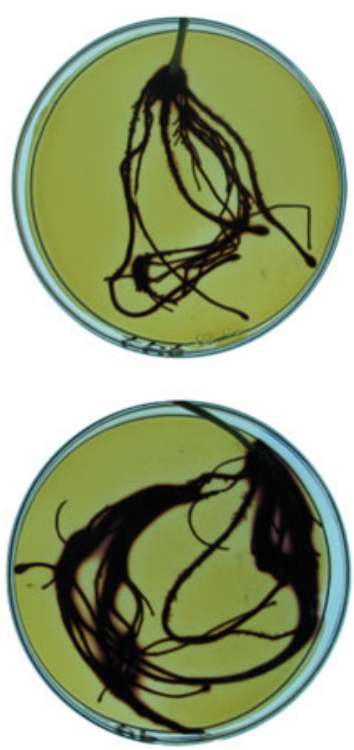

POLAR
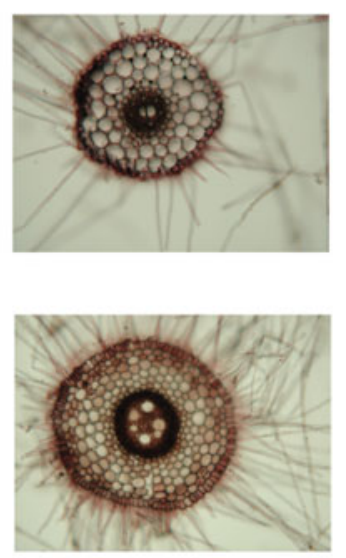

SZAKAL
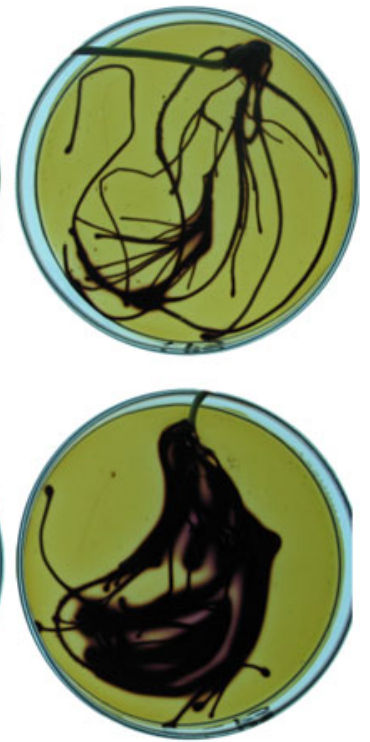

SZAKAL
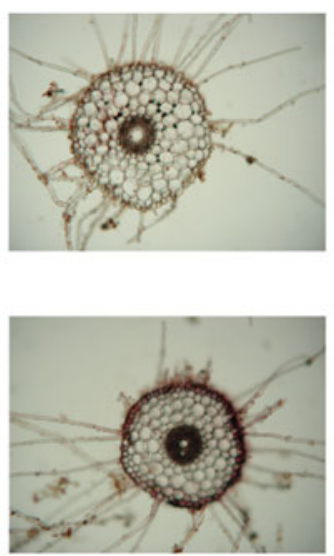

C
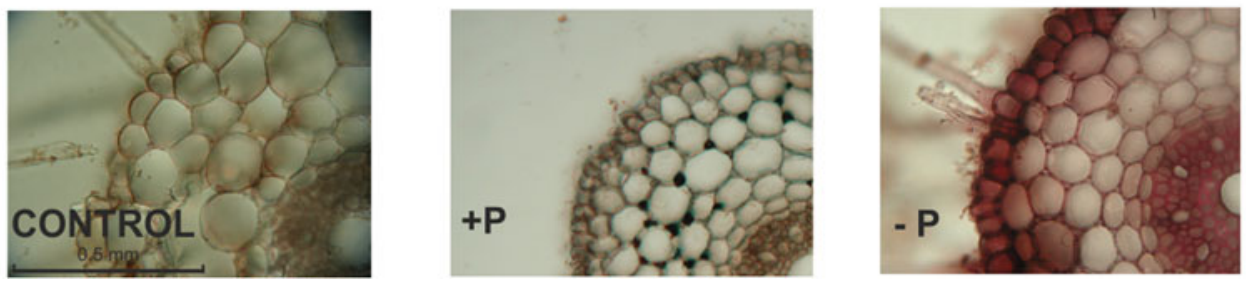

Fig. 2 In vivo staining for acid phosphatase activity in roots of three oat (Avena sativa L.) varieties (Arab, Polar, and Szakal). The dark colour indicates acid phosphatase activity in the roots and roots exudates (as compared to heat-killed tissue-control). Whole roots of plants hydroponically cultured for 1 week in phosphate-sufficient

the oat $\mathrm{cv}$. Polar. Furthermore, the highest root/shoot ratios of mass or length was observed also for Polar cultivar (Table 1). The increase of root elongation growth and root to shoot ratio is an important adaptive plant response to the low-Pi level in the soil. The enhanced changes of growth parameters in the oat cv. Polar, as compared to those of
$(+\mathrm{P})$ or phosphate-deficient $(-\mathrm{P})$ nutrient medium (a); root crosssections of plants cultured for 1 week in $+\mathrm{P}$ or $-\mathrm{P}$ nutrient media (b); selected fragments of root cross-sections from Szakal variety grown for 3 weeks in $+\mathrm{P}$ or $-\mathrm{P}$ nutrient media (c)

Arab or Szakal, were observed under Pi starvation. It seems that growth modifications are in good consistency with low-Pi concentration in tissues of Polar, better than in other oat varieties (Table 1).

Plants react to limiting Pi conditions by the induction/ repression of a subset of transcription factors, followed by 
A

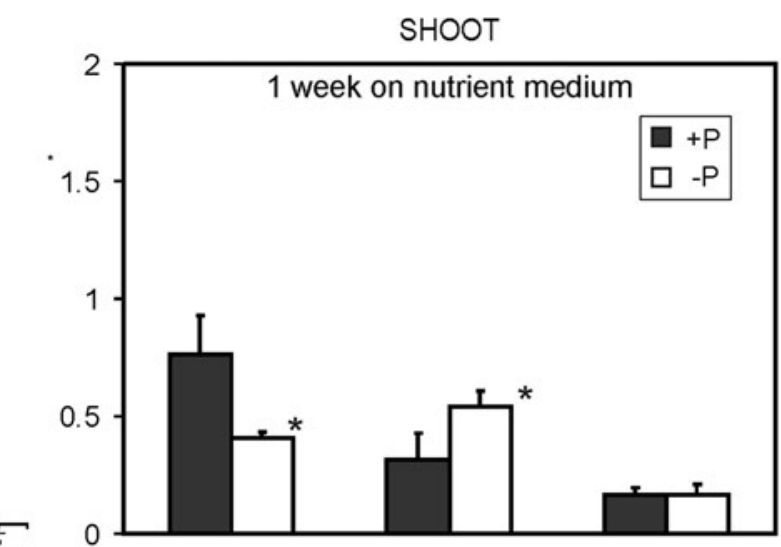

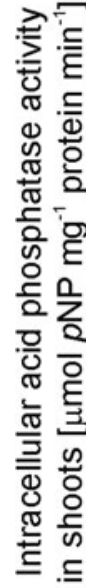
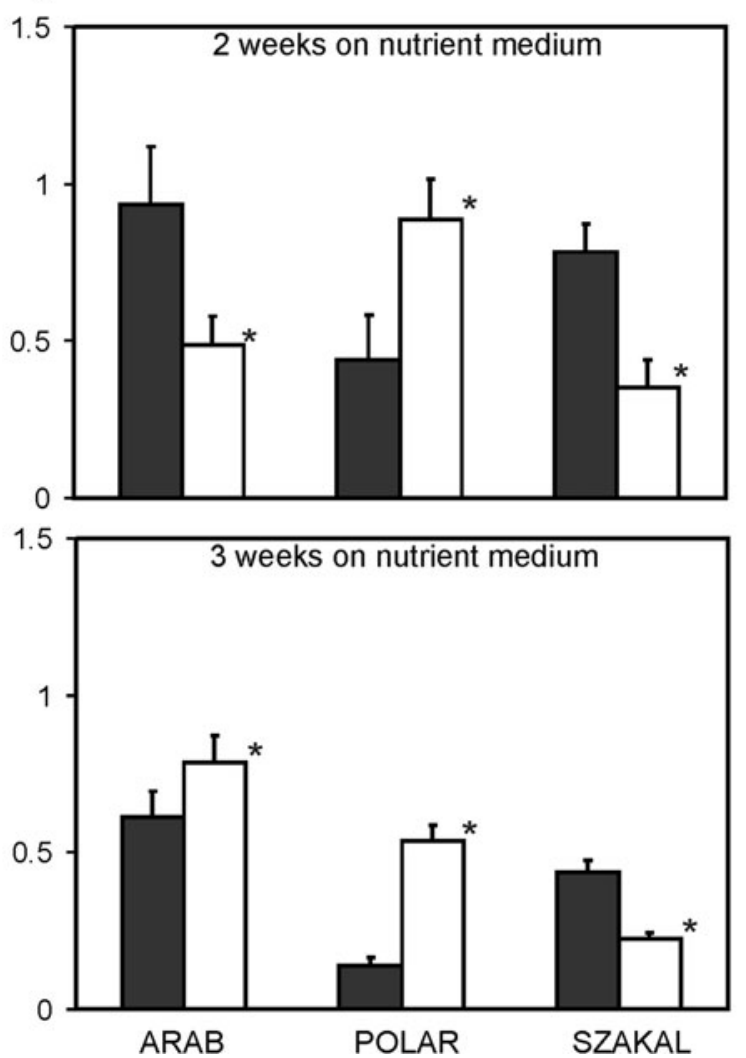

Fig. 3 Intracellular acid phosphatase activity ( $\mu \mathrm{mol} p \mathrm{NP} \mathrm{mg}^{-1}$ protein $\min ^{-1}$ ) in shoots (a) and roots (b) of three oat varieties (Avena sativa L.-Arab, Polar, and Szakal) grown for 1, 2 and

alterations of adequate genes expression (Fang et al. 2009; Nilsson et al. 2010; Lin et al. 2011). Several studies have addressed the role of transcription factors like WRKY75, PHR1, MYB62 and ZAT6 in plant growth responses to Pi starvation (Fang et al. 2009; Nilsson et al. 2010; Yang and Finnegan 2010 and papers cited therein). Recently, clusters of genes were predicted, functioning in Pi deficiency signaling; analysis of mutants defective in genes expression from "root hair cluster" revealed eight novel genes involved in Pi deficiency-induced root hair elongation (Lin et al. 2011).

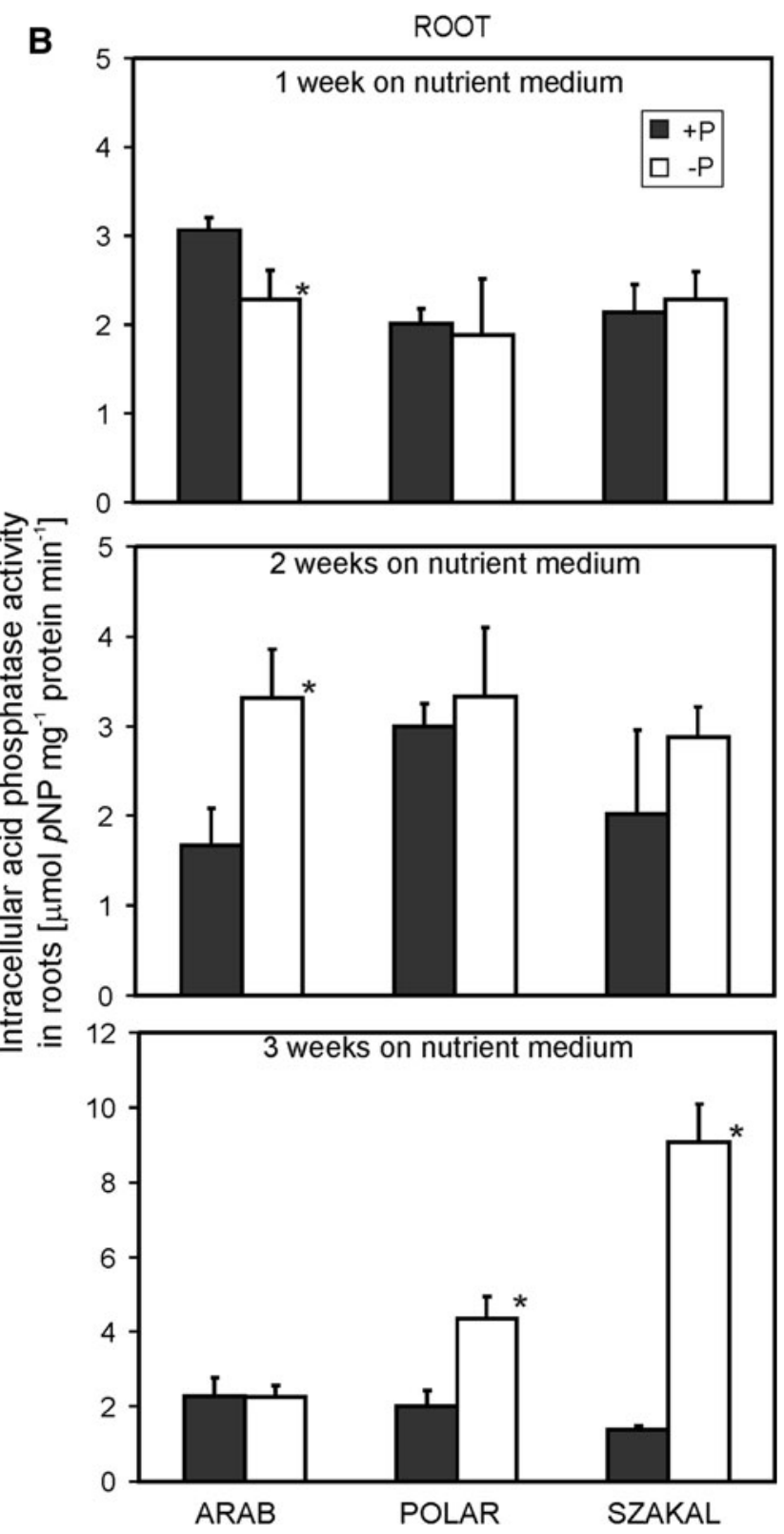

3 weeks in phosphate-sufficient $(+\mathrm{P})$ or phosphate-deficient $(-\mathrm{P})$ nutrient medium (means $\pm \mathrm{SD}$ ). Asterisk indicates differences statistically important at 0.05

Acid phosphatases activity and secretion: different oat cultivars responses to Pi depletion

Secretion of APases from oat roots can be a reaction of plants facilitating Pi availability by breakdown of organic sources of phosphorus. The highest secreted APase activity was observed in oat cv. Arab, after 3 weeks of culture under Pi-deficient conditions (Fig. 1); the growth of Arab was thus less sensitive to low-Pi stress than Polar or Szakal cultivars (Table 1). Other experiments, e.g., on rice, also indicated that root exudates, such as APases and organic 
Fig. 4 Profile of APase isoforms in crude proteins extracted from tissues of oat varieties (Avena sativa L.Arab, Polar, and Szakal) hydroponically cultured for 3 weeks in complete nutrient medium $(+\mathrm{P})$ or without phosphate $(-\mathrm{P})$. Proteins from shoots $(10 \mu \mathrm{g}$ per lane) and roots $(1 \mu \mathrm{g}$ per lane) were run on native discontinuous PAGE, stained for APase activity (4-methylumbelliferyl phosphate) and visualized under UV light
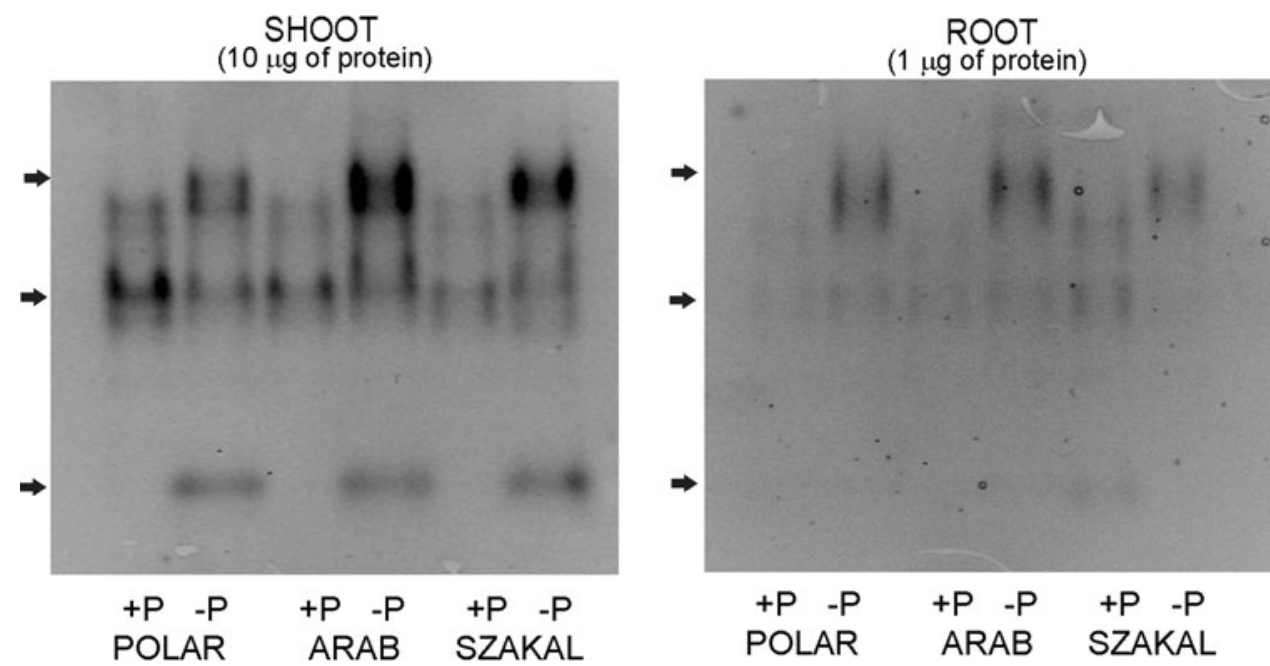

acids, were higher under phosphate deficiency in P-nonsensitive genotype than in P-sensitive genotypes (Ming et al. 2002). The extracellular APases activity was higher in root tips (than mature roots) of all the $-\mathrm{P}$ oat plants. The big difference in extracellular APase activity between control and $-\mathrm{P}$ plants was observed already after 1 week of culture (Fig. 1) which may indicate that secretion of these enzymes is an early response of plants to low-Pi stress.

The intracellular APase activity in the shoot increased mainly in the Polar cultivar grown on $-\mathrm{P}$ medium, whereas enzyme activity in roots was the highest in Pi-deficient Szakal (Fig. 3). As our results indicated, the oat varieties may use different acid phosphatases to acquire the potentially available Pi from external or internal sources under Pi starvation. In this study, the growth medium contained no $\mathrm{Pi}$, thus the measured activities of both APases possibly reflect the potentially maximal plant reaction to the nutrient stress. Further experiments are in progress for different oat cultivars grown on media containing low amounts of organic and inorganic sources of phosphorus.

Physiological adaptation to low-Pi availability can vary among genotypes of different crop plants (Asmar et al. 1995; Hunter and McManus 1999; Ming et al. 2002; George et al. 2008). Significant differences were found in the activities of soil APases in the rhizosphere of five barley cultivars (Asmar et al. 1995). Our studies indicated that other three barley cultivars slightly differed in terms of acclimation to early Pi deficiency and used similar pools of APases to acquire Pi from various sources (Ciereszko et al. 2011b). The effects of Pi deficiency on root formation and APases activity were great for the low-Pi tolerant genotypes of maize (Guame et al. 2001). Other studies found no significant variation in root-associated APases between genotypes in response to $\mathrm{Pi}$ starvation (Hunter and McManus 1999; Yun and Kaeppler 2001). In addition, George et al. (2008) suggested that despite differences in root APase activities, such variability has no significant role in $\mathrm{Pi}$ nutrition of plants grown in soil. In spite of such conflicting reports, further investigations of new crop cultivars tolerant to depletion of $\mathrm{Pi}$ in the rhizosphere are still necessary.

\section{Distribution of APase activity in root tissues}

APases activity were detected and localized on root transverse sections of all the oat varieties under study. The highest activity of enzymes was found in the epidermis and vascular tissue of $-\mathrm{P}$ roots (Fig. $2 b, c)$. The high activity of APases detected in the root epidermis (and outer cortex cells) indicated that a part of these enzymes might be secreted from the oat roots to the ground. Indeed, in vivo APase activity staining of whole oat roots showed high enzyme secretion by intact $-\mathrm{P}$ roots (Fig. $2 \mathrm{a}$ ). The results obtained in the measurements of APases activity, rootassociated and secreted, are generally in agreement with visualization of enzyme activity on root transverse sections-especially for Szakal cultivar (Figs. 1, 2, and 3).

Histochemical visualization of APases activity for cluster roots of white lupine, developed under Pi deficiency, indicated high enzyme activity in the epidermis and root hairs (Wasaki et al. 2008). LASAP2 is believed to be a major form of secreted APase, released from white lupine roots into the rhizosphere (Wasaki et al. 2009). Other studies indicated that strong expression of promoter region of secreted APases was detected in meristematic tissues of lateral roots and in the vascular tissues of $A$. thaliana under Pi starvation (Haran et al. 2000).

APases isoforms in plant tissues

Three major APase isoforms were detected in shoot and root extracts of all the oat varieties, one unique isoform (around $27 \mathrm{kDa}$ ) was induced by Pi deficiency, especially in leaf extracts (Fig. 4); no significant differences among oat cultivars were observed. Generally, in our study a 
consistency between the activity of intracellular APases (measured spectrophotometrically) and the visualization of isoforms activity was visible, at least for oat cv. Polar. However, the further subcellular localization and purification of each isoform could be useful in elucidating the role of specific APases in oat plants tissues.

Two major APase isoforms were detected in lupine root; one isoform was induced in proteoid roots under Pi-deficient conditions (Gilbert et al. 1999). Three of the four APase isoforms were induced by phosphorus stress in bean leaves (Yan et al. 2001). On the other hand, six APase isoforms were detected in soybean leaves and all increased under Pi starvation (Tian et al. 2003). In shoot and roots of rice, three APases isoforms were found; two of them were affected by Pi deprivation (Lim et al. 2003). Three APase isoforms were detected in barley shoot; one unique isoform (around 27 $\mathrm{kDa}$ ) was strongly induced by moderate $\mathrm{Pi}$ deficiency (Ciereszko et al. 2011b). However, four APase isoforms were detected in barley roots and two isoforms (approximately 80 and $27 \mathrm{kDa}$ ) were induced by Pi deficit (Ciereszko et al. 2011b). The root-associated APases pool increased in Arabidopsis when $\mathrm{Pi}$ was limiting; five isoforms was detected but one isoform increased as response to low Pi (Tomscha et al. 2004). From Pi starvation-inducible APase isoforms one is characterized as $34 \mathrm{kDa}$ monomeric protein AtACP5/AtPAP17 (Fang et al. 2009). The responses of 29 purple phosphatases were studied mainly at the transcriptional level and at least 11 PAP genes were upregulated by Pi deficiency (Fang et al. 2009 and papers cited therein).

In conclusion, the early stages of Pi deficiency induced activity of extracellular phosphatases (in the epidermis), secreted by oat roots to the ground. The growth of oat cv. Polar was more sensitive to low-Pi than other cultivars. The Arab cultivar, with less stress-sensitive growth, secretes more APases from roots. Pi deprivation increased shoot intracellular APases activity mainly in Polar cultivar, whereas enzymes activity in roots was high in oat cv. Szakal. Not all major APase isoforms detected in oat tissues were induced by Pi deficit.

Acknowledgments This work was supported by Grant from Ministry of Science and Higher Education, Poland (2007-2010, N N303 3764 33). The authors wish to thank PODR (Szepietowo, Poland) for oat seeds used in the experiments.

Open Access This article is distributed under the terms of the Creative Commons Attribution Noncommercial License which permits any noncommercial use, distribution, and reproduction in any medium, provided the original author(s) and source are credited.

\section{References}

Asmar F, Gahoonia TS, Nielsen NE (1995) Barley genotypes differ in activity of soluble extracellular phosphatase and depletion of organic phosphorus in the rhizosphere soil. Plant Soil 172:117-122

Bradford MM (1976) A rapid and sensitive method for the quantitation of microgram quantities of protein utilizing the principle of protein-dye binding. Anal Biochem 72:248-254

Ciereszko I, Kleczkowski LA (2005) Expression of several genes involved in sucrose/starch metabolism as affected by different strategies to induce phosphate deficiency in Arabidopsis. Acta Physiol Plant 27:147-155

Ciereszko I, Gniazdowska A, Mikulska M, Rychter AM (1996) Assimilate translocation in bean plants (Phaseolus vulgaris L.) during phosphate deficiency. J Plant Physiol 149:343-348

Ciereszko I, Janonis A, Kociakowska M (2002) Growth and metabolism of cucumber in phosphate-deficient conditions. J Plant Nutr 25:1115-1127

Ciereszko I, Johansson H, Kleczkowski LA (2005) Interactive effects of phosphate deficiency, sugar and light/dark conditions on gene expression of UDP-glucose pyrophosphorylase in Arabidopsis. J Plant Physiol 162:343-353

Ciereszko I, Szczygła A, Żebrowska E (2011a) Phosphate deficiency affects acid phosphatases activity and growth of two wheat varieties. J Plant Nutr 34:815-829

Ciereszko I, Żebrowska E, Ruminowicz M (2011b) Acid phosphatases and growth of barley (Hordeum vulgare L.) cultivars under diverse phosphorus nutrition. Acta Physiol Plant 33: 2355-2368

Cordell D, Drangert J-O, White S (2009) The story of phosphorus: global food security and food for thought. Global Environ Change 19:292-305

Desnos T (2008) Root branching responses to phosphate and nitrate. Curr Opin Plant Biol 11:82-87

Duff SM, Sarath G, Plaxton WC (1994) The role of acid phosphatases in plant phosphorus metabolism. Physiol Plant 90:791-800

Fang Z, Shao C, Meng Y, Wu P, Chen M (2009) Phosphate signaling in Arabidopsis and Oryza sativa. Plant Sci 176:170-180

George TS, Gregory PJ, Hocking P, Richardson AE (2008) Variation in root-associated phosphatase activities in wheat contributes to the utilization of organic $\mathrm{P}$ substrates in vitro, but does not explain differences in the P-nutrition of plants when grown in soils. Environ Exp Bot 64:239-249

Gilbert GA, Knight JD, Vance CP, Allan DL (1999) Acid phosphatase activity in phosphorus-deficient white lupin roots. Plant Cell Environ 22:801-810

Guame A, Machler F, De Leon C, Narro L, Frossard E (2001) Low-P tolerance by maize (Zea mays L.) genotypes: significance of root growth, and organic acids and acid phosphatase root exudation. Plant Soil 228:253-264

Haran S, Logendra S, Seskar M, Bratanova M, Raskin I (2000) Characterization of Arabidopsis acid phosphatase promoter and regulation of acid phosphatase expression. Plant Physiol 124:615-626

Hunter DA, McManus MT (1999) Comparison of acid phosphatases in two genotypes of white clover with different responses to applied phosphate. J Plant Nutr 22:679-692

Lim JH, Chung IM, Ryu SS, Park MR, Yun SJ (2003) Differential responses of rice acid phosphatase activities and isoforms to phosphorus deprivation. J Bioch Mol Biol 36:597-602

Lin W-D, Liao Y-Y, Yang TJW, Pan C-Y, Buckhout TJ, Schmidt W (2011) Coexpression-based clustering of Arabidopsis root genes predicts functional modules in early phosphate deficiency signaling. Plant Physiol 155:1383-1402

Maleszewski S, Ciereszko I, Skowrońska A, Mieczejko E, Kozłowska-Szerenos B (2004) Changes induced by low oxygen concentration in photosynthetic and respiratory $\mathrm{CO}_{2}$ exchange in phosphate-deficient bean leaves. Biol Plant 48:401-405 
Marschner H (1995) Mineral nutrition of higher plants. Academic Press, London

Ming F, Mi G, Zhang F, Zhu L (2002) Differential response of rice plants to low-phosphorus stress and its physiological adaptive mechanism. J Plant Nutr 25:1213-1224

Nilsson L, Muller R, Nielsen TH (2010) Dissecting the plant transcriptome and the regulatory responses to phosphate deprivation. Physiol Plant 139:129-143

Olczak M, Morawiecka B, Wątorek W (2003) Plant purple acid phosphatases: genes, structures and biological function. Acta Bioch Polon 50:1245-1256

Rychter AM, Rao IM (2005) Role of phosphorus in photosynthetic carbon metabolism. In: Pessarakli M (ed) Handbook of photosynthesis, 2nd edn. Marcel Dekker Inc, New York, pp 123-148

Schachtman DP, Reid RJ, Ayling SM (1998) Phosphorus uptake by plants:from soil to cell. Plant Physiol 116:447-453

Shane MW, Lambers H (2005) Cluster roots: a curiosity in context. Plant Soil 274:101-125

Shenoy VV, Kalagudi GM (2005) Enhancing plant phosphorus use efficiency for sustainable cropping. Biotech Adv 23:501-513

Svistoonoff S, Creff A, Reymond M, Sigoillot-Claude C, Ricaud L, Blanchet A, Nussaume L, Desnos T (2007) Root tip contact with low-phosphate media reprograms plant root architecture. Nature Genet 39:792-796

Tian J, Liao H, Wang XR, Yan XL (2003) Phosphorus starvationinduced expression of leaf acid phosphatase isoforms in soybean. Acta Bot Sinica 45:1037-1042

Tomscha JL, Trull MC, Deikman J, Lynch JP, Guiltinan MJ (2004) Phosphatase under-producer mutants have altered phosphorus relations. Plant Physiol 135:334-345

Tran HT, Hurley BA, Plaxton WC (2010) Feeding hungry plants: the role of purple acid phosphatases in phosphate nutrition. Plant Sci 179:14-27
Vance CP, Uhde-Stone C, Allan DL (2003) Phosphorus acquisition and use: critical adaptations by plants for securing a nonrenewable resource. New Phytol 157:423-447

Wasaki J, Kojima S, Maruyama H, Haase S, Osaki M, Kandeler E (2008) Localization of acid phosphatase activities in the roots of white lupin plants grown under phosphorus-deficient conditions. Soil Sci Plant Nutr 54:95-102

Wasaki J, Maruyama H, Tanaka M, Yamamura T, Dateki H, Shinamo T, Ito S, Osaki M (2009) Overexpression of LASAP2 gene for secretory acid phosphatase in white lupin improves the phosphorus uptake and growth of tobacco plants. Soil Sci Plant Nutr 55:107-113

Xiao K, Katagi H, Harrison M, Wang ZY (2006) Improved phosphorus acquisition and biomass production in Arabidopsis by transgenic expression of a purple acid phosphatase gene from M. truncatula. Plant Sci 170:191-202

Yan X, Liao H, Trull MC, Beebe SE, Lynch JP (2001) Induction of a major leaf acid phosphatase does not confer adaptation to low phosphorus availability in common bean. Plant Physiol 125: 1901-1911

Yang XJ, Finnegan PM (2010) Regulation of phosphate starvation responses in higher plants. Ann Bot 105:513-526

Yao Y, Sun H, Xu F, Zhang X, Liu S (2011) Comparative proteome analysis of metabolic changes by low phosphorus stress in two Brassica napus genotypes. Planta 233:523-537

Yun SJ, Kaeppler SM (2001) Induction of maize acid phosphatase activities under phosphorus starvation. Plant Soil 237:109-115

Żebrowska E, Ciereszko I (2007) Phosphate uptake and transport in plant cells. Adv Cell Biol 34:283-298

Żebrowska E, Ciereszko I (2009) Acid phosphatases role in plant cells phosphate homeostasis. Adv Cell Biol 36:583-599 